\title{
ForeIgN NURSING STUDENTS: THEIR PROFILE AND PERCEPTIONS OF NURSING CARE IN NAMIBIA
}

\section{Authors:}

Louis Small

Louise Pretorius

\section{Affiliations:}

${ }^{1}$ Faculty of Health Sciences, School of Nursing and Public Health, University of Namibia, Namibia

\section{Correspondence to:} Louise Pretorius

\section{email:}

pretos@iway.na

\section{Postal address:}

PO Box 30689, Pioneerspark 9000, Windhoek, Namibia

\section{Keywords:}

Namibia; clinical exposure; transcultural nursing; transcultural competence

\section{Dates:}

Received: 29 Mar. 2009

Accepted: 18 Sept. 2009

Published: 12 July 2010

How to cite this article: Small, L. \& Pretorius, L., 2010, 'Foreign nursing students: Their profile and perceptions of nursing care in Namibia', Health SA Gesondheid 15(1), Art. \#431, 8 pages. DOI: $10.4102 /$ hsag. v15i1.431

This article is available at:

http://www.hsag.co.za

\section{(c) 2010. The Authors.} Licensee: OpenJournals Publishing. This work is licensed under the

Creative Commons Attribution License.

\section{ABSTRACT}

A survey was conducted using open and close-ended questions to determine how visiting nursing students in Namibia could be assisted during their visits (cultural encounters). Many students decide to complete their clinical exposure in a foreign country, either for personal reasons or in order to meet the course requirements for transcultural nursing. Since 1998, Namibia has received a number of these students. In discussion and from passing remarks from the students themselves, the question has arisen as to how an optimum placement for each student might be achieved. Aspects of the Campina-Bacote model and The Process of Cultural Competence in the Delivery of Health Care Services were used to answer this question. It was decided to gather both biographical (profile) information and information on perceptions of nursing care in Namibia from such foreign nursing students.

The biographical (profile) information collected indicates a prevalence of certain shared biographical characteristics among international students. Such students tend to be adventurous, caring and sensitive to human rights issues. This finding correlates with the constructs of cultural desire and cultural awareness as described in the model of Campina-Bacote. Based on this finding, specific recommendations were made for clinical allocations.

From the data gathered from the open-ended questions, three themes emerged: firstly, nursing in Namibia has identifiable characteristics; secondly, there is a paternalistic and one-sided communication style among nursing caregivers in Namibia; and finally, nursing care delivery in this country is often characterised by a detached attitude. It was concluded that these themes correlated with a cultural awareness and cultural knowledge among the nursing students. The discovery of these themes was useful for making recommendations for clinical guidelines to help these students adapt, as well as for providing a foundation and substantiation for clinical placement.

\section{OPSOMMING}

' $n$ Opname bestaande uit oop en geslote vrae is uitgevoer om te bepaal hoe besoekende verpleegstudente aan Namibië ondersteun kan word (kulturele ervarings). Baie studente besluit om hulle kliniese praktika in die buiteland te voltooi, óf om persoonlike redes óf om aan kursusvereistes in transkulturele verpleging te voldoen. Sedert 1998 het Namibië 'n aantal van hierdie studente ontvang. Uit gesprekke met sowel as spontane kommentaar deur hierdie studente het die vraag ontstaan hoe hulle optimum plasing verseker kan word. Aspekte van die model van CampinaBacote, naamlik The process of cultural competence in the delivery of health care services, is benut om hierdie vraag te beantwoord. Daarom is besluit om biografiese inligting sowel as inligting oor die studente se persepsies van verpleging in Namibië in te samel.

Die biografiese inligting (profiel) het die voorkoms van sekere biografiese kenmerke onder die internasionale studente getoon: Hulle neig daartoe om avontuurlik, deernisvol en sensitief vir menseregte te wees. Dié bevinding korreleer met die konstrukte van kulturele begeertes en kulturele bewustheid soos beskryf in die model van Campina-Bacote. Op grond van hierdie bevindinge is bepaalde aanbevelings aangaande hulle kliniese plasings gemaak.

Die data deur die oop vrae verkry het drie temas gegenereer, naamlik dat verpleging in Namibië bepaalde identifiseerbare kenmerke openbaar, dat'n paternalistiese en eensydige kommunikasiestyl onder verpleegkundiges in Namibië voorkom en dat verpleegsorg deur 'n onbetrokke houding gekenmerk word. Die gevolgtrekking was dat hierdie temas met 'n kulturele bewustheid en kulturele kennis onder die verpleegstudente korreleer. Die identifisering van hierdie temas was bruikbaar as basis vir die motivering van kliniese plasings en in die maak van aanbevelings ten opsigte van kliniese riglyne om die studente te help om aan te pas.

\section{INTRODUCTION}

Over the past decade, a number of nursing students have visited Namibia from abroad. These students have made a conscious decision to experience nursing care delivery in a foreign country and specifically to experience nursing in a third-world country in Africa. Nursing-training institutions worldwide offer courses that include transcultural electives in clinical nursing and that specify the value of experience in foreign countries, especially third-world countries. This course offering has become popular because many European and North American countries accept considerable numbers of immigrants from third-world countries and because these immigrants need to be accommodated in the European and North American health care systems. This trend was recognised by Leininger and McFarland as early as 2002 (2002:579) when they wrote that, by the year 2010, the migration of people from diverse cultures and countries would increase markedly in European countries that open their doors through liberal immigration laws. In Europe, these immigrants form part of the so-called 'ethnic minorities'. In addition, there has been a worldwide migration of qualified nurses from third-world countries. Namibia 
accommodates a significant number of these professionals. These 'immigrant' nurses are expected to function in a foreign health system. In this regard, Leininger and McFarland (2002:543) are of the opinion that the ultimate goal of the transcultural nursing experience is to prepare nurses to be compassionate, competent, responsible and effective in their service to people regardless of their cultural origins or circumstances. Leininger and McFarland go on to write that comparative life-cycle patterns in health care maintenance and illness prevention will become in-depth transcultural areas of study and practice in the future (2002:583).

As a third-world country host for visiting nursing students, Namibia could broaden transcultural expertise through the knowledge and categorisation of profiles of foreign students who enrol for transcultural electives. Such background knowledge would improve clinical placement and promote intercultural competence. Intercultural competence may be defined as the ease with which someone is able to adjust and adapt to a different cultural setting (Paige, Cohen, Kappler, Chi \& Lassegard 2004:101)

More appropriate placement would also enhance foreign students' willingness to engage in cross-cultural encounters and acquire cultural competence (Weber \& Kelley 2007:19). An optimal placement would also help these nurses to adapt in a foreign culture. In a related study by Pross (2003:399), one theme that emerged was the 'adjusting' experience. Adjustment is indicated when patterns of frustration are diminished during immersion in a foreign cultural environment.

The accurate profiling of visiting students would also promote a better orientation programme design, which would prevent the forming of misconceptions regarding service in a foreign country and contribute to students' cultural knowledge. Profiling could also serve as a process for improving the quality of the local health care service, as the viewpoints of foreigners on nursing care similarities and differences are evaluated in the context of local perceptions and practices. Most importantly, profiling could form part of an adapted situation analysis. According to Uys and Gwele (2005:33), a situation analysis has to try to predict what the future will demand of graduates. This demand has been already identified in Leininger and McFarland's (2002:579) prediction (in the introduction, above) that the migration of people to European countries from diverse cultures and countries would increase markedly.

It is therefore necessary for nursing students from these countries to acquire the knowledge, skills and attitudes needed for transcultural nursing. With regard to transcultural nursing, this specifically refers to the idea that how one learns may be more important that what one learns. Future nursing professionals might be shaped more by the attitudes, vision and inspiration they internalise during their education than by the content they have been taught (Uys \& Gwele 2005:33). This internalisation could be accomplished in a foreign country, like Namibia, and planning should be done to make sure that optimum cultural encounters occur.

\section{Background}

Student nurses who choose Namibia for completing a transcultural elective appear to share certain characteristics and perceptions which underlie their decisions. A proper evaluation of these characteristics could assist in the clinical placement of these students through the compilation of a 'nursing profile'. Such a profile could, to a certain extent, help predict the likelihood of successful adaptation to the foreign country. Foreign students also enrol in international electives in order to acquire additional 'caring' skills, which will develop the capacity to empathise with foreign, minority or immigrant patients and clients. This reason for enrolment could be called a 'cultural desire'. CampinaBacote (2003:6) define a cultural desire as a nurse's motivation to 'want to' engage in the process of becoming culturally aware and skilful and seeking cultural encounters.
Foreign students' personal anecdotes about experiences of nursing care in Namibia and how their own perspectives were challenged could help in compiling educational support material and in facilitating correct clinical placements. If the information gained is compared with students' profiles (biographical information), then more optimum placements or cultural encounters can be arranged. The notion of correct placement is supported by Papp, Markkanen and Von Bonsdorf $(2003: 267)$, who state that student nurses place a high value on clinical practice and the growth possibilities it offers in the process of becoming a mature, professional nurse. More effective placement would also assist these nurses to become culturally competent. The above discussion leads to the formulation of the problem statement.

\section{PROBLEM STATEMENT}

Owing to a lack of information on foreign nursing students and their perceptions of nursing care in Namibia, it was not possible to make (an) optimum clinical placement(s). The purpose of the study was therefore formulated on the basis of the problem statement.

\section{Purpose of the study}

The purpose of this study was to explore and describe the profile of foreign nursing students, as well as their perceptions of nursing care in Namibia.

\section{RESEARCH OBJECTIVE}

Objectives derived from the research purpose were to:

- $\quad$ explore and describe a profile for visiting nursing students in the context of demographic profiles

- explore and describe their perceptions of cultural differences and similarities with regard to the delivery of nursing care

- submit recommendations to ensure optimum clinical placements.

\section{A cultural care model as framework}

Culture diversity is the standard in many hospitals in Europe and Northern America. From there, nursing students apply to visit Namibia. For this reason, Leininger developed transcultural nursing, which has as its main goal the provision of culturally specific care. There are, however, other studies that have been conducted and other models that have been suggested in the field of transcultural care (Tortumluoglu 2006:2).

This study used constructs derived from a model developed by Campina-Bacote (2003:1-11). This model is known as The Process of Competence in the Delivery of Health Care Services Model, and includes certain constructs that a student nurse needs to internalise and/or acquire in order to become culturally competent. These constructs include cultural desire, cultural awareness, cultural knowledge, cultural skills and cultural encounters. Culture in its broader sense has a variety of definitions but it could be regarded as being learnt or constructed and consisting of inherent attitudes and values that are shared and transmitted among its members (Leininger in George 1995:375)

A cultural desire is defined as a nurse's motivation to 'want to' engage in the process of becoming culturally aware, culturally knowledgeable and culturally skilful, and to seek cultural encounters. It is the key construct of cultural competence, as it sets the entire process of cultural competence in motion (Campina-Bacote 2003:4).

Cultural awareness is defined as the process of conducting the self-examination of one's own biases towards other cultures and the in-depth exploration of one's cultural and professional background (Tortumluoglu 2006:8). Cultural knowledge, in 
contradistinction, is the process of seeking and obtaining a sound educational foundation about diverse cultural and ethnic groups. This involves an understanding of these groups' and patients' worldviews. The patients' worldviews will explain how they interpret their illness and how this interpretation guides their thinking, doing and being (Campina-Bacote 2003:6).

Cultural skill is the ability to collect relevant cultural data on the client/patient's presenting problem, as well as the ability to perform culturally based physical assessments (CampinaBacote 2003:7)

A construct that was regarded as crucial for this study was the construct of cultural encounters. This is the process that encourages the nurse to interact directly with clients of culturally diverse backgrounds (Campina-Bacote 2003:7). These encounters are necessary in order to become culturally competent and to avoid prejudice and ethnocentrism.

\section{RESEARCH METHOD AND DESIGN}

A survey with open-ended and closed-ended questions was conducted. The study was also contextual because it only investigated visiting foreign nursing students to Namibia.

To achieve the first objective, a quantitative approach was used, whereas two open-ended questions were used to attain the second objective. These open-ended questions were required to evaluate students' subjective responses.

\section{Population and sampling}

The population for the survey consisted of all foreign nursing students who were in Namibia between January and November
2007. The accessible population was 42 individuals, all of which were included in the study.

\section{Data collection}

The students were asked to complete a questionnaire consisting of open-ended and two closed-ended questions (see Table 1).

The closed-ended questions focused on biographical information and a self-rating scale for measuring how they perceived themselves in terms of certain characteristics that might be related to interest in clinical exposure in a foreign country. Ordinal scales were used for the self-ranking. In this type of scale, the quantity in which a certain attribute is possessed is identified by the nursing students themselves. This type of scale is sometimes also referred to as an ordered metric scale (Burns \& Grove 2005:372).

Two open-ended questions were formulated to encourage the respondents to describe their perceptions of cultural similarities and differences (see Table 1).

Table 2 gives an indication of the questionnaire's correlation with the model (A Model of Cultural Competence).

\section{Data analysis}

The quantitative data were analysed descriptively. The sum of the different responses were given and mean (average) values were calculated in the analysis of the data.

The data from the open-ended questions was analysed according to Tech's method (cited in Creswell 1998:190-195) by coding data and identifying the themes and subthemes. According to

TABLE 1

Research instrument: Profile of visiting nursing students and their perceptions of nursing care in Namibia

\begin{tabular}{lll}
\hline Demographic profile & Self-rating with regard to certain characteristics & $\begin{array}{l}\text { Perceptions of cultural similarities and differences with regard } \\
\text { to nursing care }\end{array}$ \\
\hline Age & Being adventurous & $\begin{array}{l}\text { Similarities with regard to nursing care in Namibia and their terms } \\
\text { of reference. } \\
\text { Gender }\end{array}$ \\
Country of origin & Religious orientation & $\begin{array}{l}\text { Differences with regard to nursing care in Namibia and their terms } \\
\text { of reference. }\end{array}$ \\
Academic year & Advocate for human rights & - \\
Area of interest with regard to nursing practice & - & - \\
City/town of origin & - & - \\
\hline
\end{tabular}

TABLE 2

Correlation of the instrument and the students' visit to Namibia with the model (The Process of Competence in the Delivery of Health care Services Model)

\begin{tabular}{|c|c|c|}
\hline Question & Construct in the model & Comments \\
\hline The actual visit to Namibia by the students. & Cultural desire & $\begin{array}{l}\text { These students engaged in obtaining loans and bursaries to enable their } \\
\text { visit to Namibia. }\end{array}$ \\
\hline Self-rating scale on caring. & - & Cultural desire involves the concept of caring (Campina-Bacote 2003:4). \\
\hline The open-ended questions on similarities and differences. & - & $\begin{array}{l}\text { In developing a culturally responsive approach to care, the nurse must } \\
\text { recognise differences but build on similarities (Campina-Bacote 2003:5). }\end{array}$ \\
\hline
\end{tabular}


this method, the students' comments were first read to obtain a general overview and then the most interesting anecdote or comment was evaluated. Patterns were established and these were later grouped together as themes. A literature control was carried out to verify the results and to place them in the context of an established body of knowledge.

\section{ETHICAL CONSIDERATIONS}

Informed consent was obtained. The nursing students received the assurance that their responses would be treated with confidentiality and that they would remain anonymous.

\section{TRUSTWORTHINESS}

The instrument that was used for the quantitative data was tested for validity and reliability, while methods deemed trustworthy were employed for the qualitative data.

Trustworthiness is about assessing the truth value of qualitative data (Polit \& Beck 2006:332). In this study the data from the two open-ended questions were analysed using a qualitative approach and thus the principle of trustworthiness was used as well. In this study, Guba's model, cited in Krefting (1991:241222), was used to ensure trustworthiness. This model is well developed conceptually and has been used extensively by qualitative researchers, particularly nurses and educators, for a number of years (Krefting 1991:215).

The following four criteria to ensure trustworthiness were applied: truth value, applicability, consistency, and neutrality. The application of strategies of credibility ensures truth values, while the application of strategies of transferability ensures applicability. To ensure consistency, strategies of dependability were applied; to ensure neutrality, strategies of confirmability were applied.

A short schematic presentation is provided to indicate how trustworthiness was ensured in the study (see Table 3).

\section{Validity and reliability}

Validity addresses whether the instrument actually tests the intended parameters or factors. In this study the validity component of the instrument dealt mainly with face and content validity. The main focus was a profile of nursing students, as it was assumed that this information was necessary to correctly allocate the students for their cultural encounters, as well as to determine their 'progress' in becoming culturally competent. In this regard the instrument demonstrated face validity. To ensure content validity, the instrument was related to The Process of Cultural Competence in the Delivery of Health Care Services model (Campina-Bacote 2003:1-11).

Reliability refers to the consistency of results produced by an instrument. In this study the process of equivalence was used (Burns \& Grove 2005:374) and the instrument was assessed by two researchers who obtained the same results when the instrument was administered to two students. This assessment was completed as part of a pilot study and no changes were made to the instrument.

\section{DISCUSSION}

Findings from the quantitative analysis will be discussed first. Eleven items were constructed. These items included biographical data as well as ratings on how visiting students perceived themselves with regard to certain value and belief systems. Table 1 provides a tabular depiction. The first item dealt with the age distribution of the nursing students.

\section{Item 1: Age distribution}

The majority of the nursing students included in the study were young adults. The average age of the population was 25 years, with $72 \%(N=29)$ of the students falling into an age distribution of 20-24 years. In similar studies of nursing students allocated to foreign countries, it was found that age at the time of their tour positively correlated with personal development, suggesting that personal development was greater with older students

TABLE 3

A schematic presentation of the strategies for establishing trustworthiness together with their criteria and implementation in the study

\begin{tabular}{|c|c|c|}
\hline Strategy & Criteria & Implementation \\
\hline \multirow[t]{9}{*}{ Truth value (credibility) } & Prolonged engagement & Enough time was allowed to become acquainted and to establish a trusting relationship with the participants. \\
\hline & & $\begin{array}{l}\text { One of the researchers was the coordinator of these students and had weekly meetings with them for their entire } \\
\text { period of stay, which ranged between eight and twelve weeks. Apart from the scheduled meetings she was also } \\
\text { contacted in the case of any problem related to accommodation and clinical practice, and even personal problems. }\end{array}$ \\
\hline & Reflexivity & The researchers also participated in the research and were not just observers. \\
\hline & Time sampling & $\begin{array}{l}\text { The meeting with the students was preceded by a settling down time during which the nature and purpose of the } \\
\text { study was explained. }\end{array}$ \\
\hline & & A couple of months were needed to prepare for this research. \\
\hline & & A pilot study was undertaken. \\
\hline & Member checking & $\begin{array}{l}\text { The involvement of the participants was to ensure that the research findings were a true reflection of their } \\
\text { experiences. }\end{array}$ \\
\hline & & Follow-up interviews were conducted to clarify themes identified in the data collected. \\
\hline & Peer examination & An independent coder was used. After discussions an agreement was reached on the credibility of the analysis. \\
\hline \multirow[t]{2}{*}{ Applicability } & Dense description & A demographic description of the participants formed an integral part of the findings. \\
\hline & & Rich descriptions of findings were done. \\
\hline Consistency & Dense description & $\begin{array}{l}\text { A full description of the data collection and data analysis methods is provided in order for other researchers to } \\
\text { trace the methods used. }\end{array}$ \\
\hline \multirow[t]{2}{*}{ Confirmability } & Audit trail and audit process & An audit trail was maintained by keeping personal notes and field notes. \\
\hline & Reflexivity & As discussed under 'Truth value'. \\
\hline
\end{tabular}




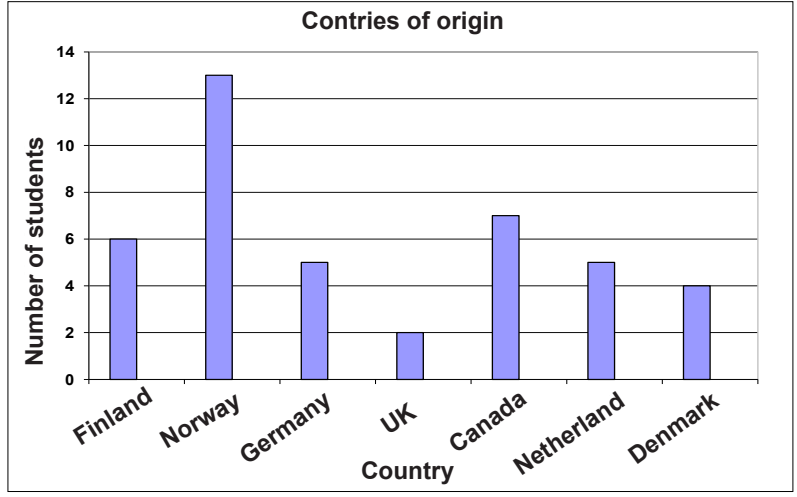

FIGURE 1

Country of origin of the visiting nursing students $(N=42)$

(Pross 2003:397). The assumption is therefore that these nursing students could be regarded as mature and should therefore be able to adjust in the areas selected for clinical exposure.

\section{Item 2: Gender of visiting student nurses}

Eighty-eight percent $(N=37)$ of the participants were female.

\section{Item 3: Country of origin}

Figure 1 provides a bar chart showing the countries of origin of the visiting students:

As the figure indicates, all the nursing students included in the study were from first-world countries in Europe and North America, which have well-established health services with a welldeveloped infrastructure. These countries also acknowledge that the health care needs of minority ethnic groups are not being adequately met, that they receive a large number of immigrants annually and, consequently, have to cater for a relatively large immigrant population (Narayanasamy \& White 2005:103).

\section{Item 4: Cities or towns originsted}

Item 4 focused on the cities or towns from which the students originated. All the Norwegian students came from Elverum, six of the seven Canadian students were from Victoria, with the remaining student hailing from Vancouver. The Danish students came from Slagelse, the Finnish students from Helsinki, Kotka and Espoo-Vantaa, and the German students indicated that Berlin and Ulm were their home towns. The students from the Netherlands came from Deventer, Utrecht and Leeuwaarden.

Agreements have been put in place between the University of Namibia and the schools in which these students have been enrolled, specifically to accommodate the transcultural elective in their curricula.

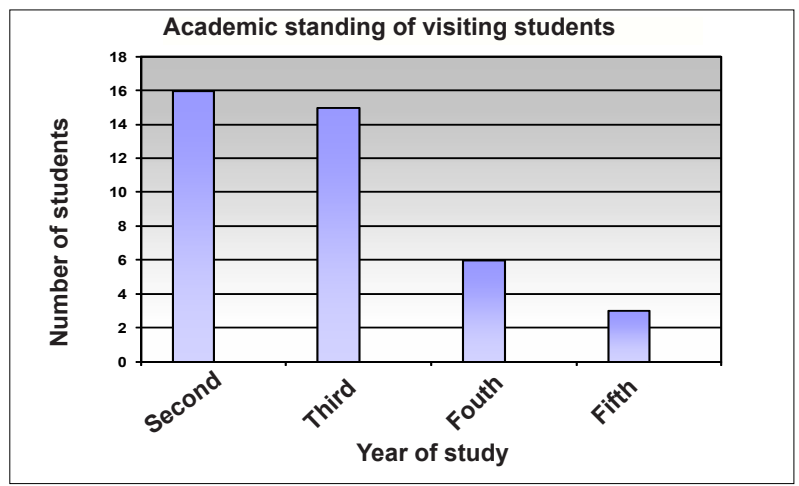

FIGURE 2

Academic year of training of the visiting nursing students

\section{Item 5: Year of training}

Figure 2 indicates the students' current academic year.

From Figure 2, it can be seen that the majority of students visit Namibia towards the end of their second academic year. It appears that the training institutions and nursing departments want to instil cultural awareness in their students as early as possible. Cultural awareness may be defined as the deliberate cognitive process by which a health care provider becomes appreciative and sensitive to the values, beliefs, lifestyle, practices and problem-solving strategies of a client (Weber \& Kelley 2007:19). This finding also indicates that these students are still progressing through a learning curve and thus might not yet have internalised basic (fundamental) nursing skills. This in turn might influence the type and extent of the accompanying guidance required.

\section{Item 6: Area of health care or nursing}

Under Item 6, the respondents were asked to indicate the area of health care or nursing in which they were most interested. This item was necessary in order to identify relevant areas where these nursing students could be allocated for appropriate cultural encounters. Eighteen fields were indicated.

The three prominent choices were surgery, $17 \%(N=7)$, paediatrics, $14 \%(N=6)$, and psychiatry, $9.5 \%(N=4)$. An interesting choice was trauma nursing, which was selected as a second choice by $19 \%(N=8)$ of the respondents. The next choice of second preference was acute care nursing, which received a $12 \%(N=5)$ indication rate. In conversations with the students, it was mentioned that although they were exposed to these units in their own countries, their nursing roles were more observational than interventional (Pretorius 2009).

Items 7 to 10 contained ordinal questions in which the respondents were required to rate themselves on a five-point scale for a set of characteristics and beliefs.

\section{Item 7: Adventurous nature}

According to Payne (2004:17), in order to become culturally competent one needs to seek experiences that will help shape one's worldview. It requires an adventurous individual to leave the familiarity of their home in a first-world country for a transcultural elective, particularly in a third-world country in Africa.

Under Item 7 the respondents had to rate themselves on how adventurous they regarded themselves as being. A rating of $\mathbf{1}$ indicated 'not very adventurous'; while a rating of 5 meant the respondent believed he or she was 'very adventurous'.

An average rating of 3.95 out of 5 was obtained from the sample.

The high self-rating average of 3.95 is descriptive of an adventurous individual and these nursing students certainly exhibit this character trait. Based on this self-rating average, one could also assume that these students meet the criteria for exhibiting a 'cultural desire'.

\section{Item 8: Religious convictions}

Item 8 asked the respondents to rate their religious convictions. This item was included to determine the necessity of allocating students to missionary hospitals. Again, 1 indicates a low rating, while 5 is the highest. An average rating of 2.02 out of 5 was obtained.

It appears that these visiting nursing students were not necessarily motivated by religious convictions to embark on their field trip to Namibia. 
TABLE 4

Themes and patterns that emerged from the open-ended questions

\begin{tabular}{lll}
\hline Open-ended questions & Pattern & Themes \\
\hline $\begin{array}{l}\text { Describe your perceptions of the cultural similarities from your } \\
\text { frame of reference that you have noticed. }\end{array}$ & Similar philosophical underpinnings of nursing & $\begin{array}{l}\text { Nursing in Namibia has similar internationally identifiable } \\
\text { characteristics }\end{array}$ \\
$\begin{array}{lll}\text { Describe your perceptions on the cultural differences from your } \\
\text { frame of reference that you have noticed. }\end{array}$ & $\begin{array}{l}\text { Similar curricular content } \\
\text { Ineffective communication }\end{array}$ & $\begin{array}{l}\text { Indifference, or the absence of a reaction, to } \\
\text { cues of emotional and physical distress } \\
\text { Delayed reaction to: } \\
\text { - situations } \\
\text {-impatience }\end{array}$ \\
\hline
\end{tabular}

\section{Item 9: Human rights advocates}

The respondents were asked to rate themselves as human rights advocates on a scale, with ' 1 ' indicating a low rating, and ' 5 ' indicating a high rating. The inclusion of this item was based on the assumption that cultural awareness depends on recognising one's biases, prejudices and assumptions about individuals, which includes their rights. Without being aware of the influence of one's own cultural values and assumptions on the rights of individuals (patients), there is the risk that the nurse may engage in cultural imposition (Campina-Bacote 2003:5). An average score of 3.83 out of 5 was obtained. It is assumed that these students regarded themselves as advocates of the rights of individuals, thus they may be inclined to possible cultural imposition.

\section{Item 10: Caring abilities}

Item 10 addressed self-assessment on caring abilities. An average score of 4.4 out of 5 was obtained. It is assumed that this group of nursing students regarded themselves as possessing caring abilities. Based on the model, The Process of Cultural Competence in the Delivery of Health Care Services, cultural desire involves the concept of caring (Campina-Bacote 2003:4). It thus appears that the student nurses in this study had the necessary cultural desire to become culturally competent.

In general, Items 7 to 10 also provided some information on the personal development of these nursing students. Personal development relates to the affective development of learners. Appropriate personal development could be regarded as existing when students are aware of their personal abilities and accept themselves with regard to their temperament, talents and interests (Meyer \& van Niekerk 2008:90). It appears that these students were aware of their personal abilities, as well as their talents and interests.

\section{Items 11 and 12: Cultural similarities and differences}

Items 11 and 12 each contained an open-ended question formulated as follows:

Describe your perceptions of the cultural 'similarities' (Item 11) and cultural 'differences' (Item 12) from your frame of reference that you have noticed.

With the analysis of these two open-ended questions, three themes emerged, one emerging from the question on perceptions of cultural similarities and two emerging from the question on cultural differences. In Table 4 , an outline is provided of these themes and patterns.

\section{Theme 1: Nursing in Namibia has internationally identifiable characteristics}

The visiting student nurses identified the following patterns to which they could relate:

- Philosophical underpinnings of nursing

- Similar curriculum content.
These two patterns indicate the probable development of intercultural sensitivity on the part of the visiting students. Intercultural sensitivity is defined as possessing a developed awareness and understanding of another culture which accompanies the educational experience (Paige et al 2004:101). This statement will be substantiated under the discussion of each pattern using applicable quotations.

- Philosophical underpinnings of nursing

One student made the following comment:

'Nursing ideologies and training are similar [in Namibia and abroad] and it was easy to relate to Namibian nursing students'

This statement indicates 'acceptance', or an ethno-relative stage of development, in which one's own culture is not viewed as the standard against which another culture should be judged (Paige et al. 2004:103). This stage correlates with the view that different cultures display a high degree of similarity (Du Toit \& Van Staden 1989:27).

- Similar curriculum content

'The nursing students seem to learning [sic] the same things we are learning and seem to be interested in what they are learning.'

Another comment which represents a similar view:

'Nurses know what they are doing and drugs and treatment are the same.'

These comments indicate the possible recognition of an aspect of universality between visiting students and Namibian nurses, namely that specific curriculum content, common to both cultures, requires mastery in order for student to become a competent nurse. Leininger (1991:47) describes cultural care universality as part of a way of life that manifests itself similarly in many cultures.

\section{Theme 2: A paternalistic, one-sided communication style}

Communication receives a great deal of emphasis in nursing education worldwide. This focus is appropriate since nurses are constantly in dialogue with their clients and patients. The participants made a number of comments on the style of communication they had observed and experienced in Namibia. The following reflects some of their comments:

'There also seemed to be a number of situations where staff would argue with patients, especially in ...

It appeared as if these visiting nursing students had perceptions of a 'power' display by the nurses of the host country. Power is said to be negotiated in each encounter and context and is mediated by social signifiers such as culture and class (Payne 2004:14). In this study the participants in the study were allocated to clinical areas where the clientele were mainly poor, and thus in a different 'class' if compared with the nurses of the host country.

Another comment was:

'... most of the time the nurses don't say what will happen with the patient [sic]. 
This perception from the visiting nursing students touched on the aspect of patient autonomy, which endorses the rights of individuals for truthful disclosures (Payne 2004:21). This perception could be regarded as a 'dismissal' of patients' autonomy, and thus their human rights.

The communication style between nursing professionals was also perceived as being defensive to an extent. One comment that hinted at such a perception was worded as follows:

'Down here the older sisters get angry if younger students say anything to her about the job.' [sic]

One educational philosophy inherent in all nursing curricula in Namibia is that of adult education. This philosophy, as described in Knowles's process model, acknowledges the contribution of the nurse as adult learner, as well as their right to question and query (Quinn \& Hughes 2007:30).

\section{Theme 3: Detached nursing care delivery}

The above theme emerged from patterns indicating what appeared to be a deliberate lack of caring, or an inability to internalise the needs of patients, which may not have been deliberate.

Three patterns that were identified are the following:

- indifference, or the absence of a reaction, to cues of emotional and physical distress

- delayed reaction to situations

- impatience.

The following students' comments shed light on their perceptions about the existence of these three patterns. These are presented individually below.

Indifference, or no reaction to cues of emotional and physical distress

The issue of indifference was readily and often mentioned by the visiting nursing students. Some of these comments were about the lack of compassion or empathy. Examples of indifference were as follows:

'I did not see much compassion or empathy ...' [sic]

'It was hard to come to a setting where lack of compassion and care seemed so prominent.' [sic]

Another observation that was made by a student was:

'I have found that Namibian nurses have a very impersonal way of dealing with their patients which seems to us to be uncaring.'

The perception was also echoed by Namibian nursing students as early as 2000 in an unpublished postgraduate study by $\mathrm{Wu}$ (2000:40). In this study, focusing on the interpersonal communication and caring experiences of student nurses, the participants indicated that they sometimes felt discouraged by the noncaring attitudes of nurses.

A perception of financial motivation rather that a 'caring' motivation was implicit in the career choices of some Namibian nurses.

'Nurses often told me they chose the career because it was money [sic], and not many said it was because they wanted to care ...'.

The reality in Namibia is that there is a shortage of employment opportunities, and people will grasp at any opportunity to be employed. The above quotation also hinted at the possibility of cultural imposition. Cultural imposition is the tendency to impose one's beliefs, values and patterns of behaviour on another culture (Campina-Bacote 2003:11).

Another perception was that of ethnocentrism and it was conveyed as follows:

'... that nurses care more about their own type [sic] '.

It is possible that indifference, in some cases, might be based on tribalism, which is linked to prejudice based on one's ethnic group. This could also be called ethnocentrism. In its most severe form, it presents as an authoritarian dominance over groups different from one's own (Payne 2004:10).

\section{Delayed reaction to situations}

Comments were made which indicated that nurses either did not react to patients who were in pain, or did so only after an amount of time had passed. One student made the comment:

'At first I really was shocked that a patient felt pain and nobody cared about it.'

Another student commented as follows:

'... was in casualties where you sometimes can see really painful patients, and it sometimes take really long that they are getting pain medication' [sic]

The differences in 'time value' has also been commented on by Leininger (in Leininger \& McFarland 2002:292-293). This author emphasises the fact that there are a few cultures in the world where time is not the central focus for living and wellbeing. In the context of the Namibian situation and the timely administering of analgesics, an expectation is that the needs of the patient should be a priority.

\section{Impatience}

'I also have found many nursing sisters to be abrupt with their patients.' [sic]

A pattern of impatience seemed to emerge owing to a lack of compassion. This might also reflect an attitude of indifference regarding patients' rights.

\section{RECOMMENDATIONS}

Recommendations with regard to clinical placement options (cultural encounters) and supportive educational material were constructed, and are based on the constructs of CampinaBacote's model. This model advocates the experientialphenomenological perspective of culture. Nurse educators can use the model to teach nurses how to deliver culturally competent nursing care by incorporating its constructs in an education programme (Brathwaite 2003:1-10).

A separate recommendation was submitted, namely to conduct an information session with the Department of Nursing at the University of Namibia regarding these findings. The recommendations of the survey are discussed next.

\section{Cultural encounters}

\section{Clinical placement options}

With an average age of 25 , the nursing students who visited Namibia appear to be mature individuals. They rated themselves as being very adventurous, with an average personal rating of 3.95 out of 5 . In addition, they regarded themselves as being caring individuals and supporters of human rights. Their clinical preferences were surgery, paediatrics and psychiatry, with trauma nursing the second choice of $19 \%(N=8)$ of the students.

Based on these character traits, it would be reasonable to place visiting students in locations regarded as challenging, such as rural areas with few amenities. Namibia has conditions which would expose students to facilities possessing only rudimentary essentials, even some which have no electricity or running water. A large number of the patients they would see would be children under the age of five. The possibility of encounters with mental health patients would be high and they would also be exposed to trauma patients. As medical practitioners are not available in many areas, they would be expected to assist these patients only with the supervision of a registered nurse. Working conditions are often not very pleasant and a significant number of patients might be suffering from HIV or AIDS. Only dedicated and 
caring nurses would be able to cope in such situations which are common in the country.

In the past, visiting nursing students have been shielded from exposure to such conditions. The recommendation is therefore to identify challenging clinical areas and place visiting students there for their cultural encounters.

\section{Cultural knowledge and cultural skills Supportive educational material}

In a study, Marcinkiw (2003:178) refers to the importance of incorporating cultural information throughout the nursing curriculum. When students arrive in Namibia for clinical exposure, this phase of training could be regarded as a continuation of their curriculum. The emergence of the three themes from the perspective of visiting students indicates that there is a need to explain some of their experiences in terms of the cultural context. To accomplish this, additional educational material will be required. The following topics need to be included in an orientation programme.

\section{An introduction to the nursing and health care philosophy of Namibia}

This inclusion could lead to a strengthening of their cultural knowledge, specifically in terms of the similarities between Namibia's nursing philosophy and that of their own countries.

\section{Provision should be made in The Namibian Scope of Practice to emphasise the importance of an holistic approach to nursing care}

This provision should take into consideration the communication needs of patients and should also highlight the idea that although cultural differences affect communication, certain universal principles still apply. These principles, which include attentiveness, openness and courtesy, should be observed by all nurses in Namibia. This could assist with the acquisition of a potentially deeper cultural knowledge and cultural skills.

\section{A brief description of the diverse cultures which coexist in Namibia}

A cultural overview, while acknowledging our cultural diversity, could demonstrate that the observance of basic principles of communication is essential to effective and conscientious health care delivery. This would also enhance foreign students' cultural skills and cultural knowledge.

Deviation from sound principles of communication on the part of Namibian nurses should be attributed to personal attitudes and should not be viewed as cultural traits. This comment is supported by Campina-Bacote, as quoted in Brathwaite (2003:1$10)$, when she states that culture is dynamic and fluid and there is more variation within a culture than among different cultures.

\section{CONCLUSION}

This study revealed that Namibia attracts nursing students who share certain character traits. They are in their mid-twenties, they consider themselves to be adventurous, caring and advocates of human rights. Their clinical preferences are diverse and include the disciplines of surgery, paediatrics and psychiatry as primary choices, with trauma nursing an interesting second choice. Their experiences of cultural similarities and cultural differences lead to the identification of three themes exhibited by nursing care in Namibia - namely, that nursing in Namibia has internationally identifiable characteristics, a paternalistic, one-sided communication style and nursing care delivery is often done in a detached manner. From these findings, recommendations were formulated to facilitate optimal clinical placement as well as provide visiting students with supportive educational material.

\section{REFERENCES}

Brathwaite, A.C., 2003, 'Selection of a conceptual model/ framework for guiding research interventions', Internet Journal of Advanced Nursing Practice 6(1), 1-10.

Burns, N. \& Grove, S.K., 2005, The practice of nursing research: Conduct critique, and utilization, St. Louis, Mo., Elsevier Saunders.

Campina-Bacote, J., 2003, 'Many faces: Addressing diversity in health care', Online Journal of Issues in Nursing 8(1), viewed 10 March 2009, from http://nursing world.org/ojin/topic20/ tpc20_2.html.

Creswell, J.W., 1998, Research design: Qualitative and quantitative approaches, Sage, California

Du Toit, D.A. \& Van Staden, S.J., 1989, Nursing sociology, Academia, Pretoria.

George, J.B., 1995, Nursing theories: The base for professional nursing practice, Norwalk, Appleton \& Lange.

Krefting, L., 1991, 'Rigour in qualitative research: Assessment of trustworthiness', American Journal of Occupational Therapy 45(3), 214-222.

Leininger, M. (ed.), 1991, Culture care diversity $\mathcal{E}$ universality: A theory of nursing, New York, National League for Nursing Press, New York.

Leininger, M. \& McFarland, M.R., 2002, Transcultural nursing: Concepts, theories, research $\mathcal{E}$ practice, McGraw-Hill, New York.

Marcinkiw, K.L., 2003, 'A goal for nursing education', Nurse Education Today 23(3), 174-182.

Meyer, S. \& Van Niekerk, S., 2008, Nurse educator in practice, Cape Town, Juta.

Narayanasamy, A.M. \& White, E., 2005, 'A review of transcultural nursing', Nurse Education Today 25(2), 102-111.

Paige, R.M., Cohen, A.D., Kappler, G., Chi, J.C. \& Lassegard, JP 2004, Maximizing study abroad: A students' guide to strategies for language and culture learning and use, University of Minnesota, Minnesota.

Papp, I., Markkanen, M. \& von Bonsdorff, M., 2003, 'Clinical environment as a learning environment: Student nurses' perceptions concerning clinical learning experiences', Nurse Education Today 23(4), 262-268.

Payne, H., 2004, December, 'Closing the gap: A journey to cultural safety', Intercultural Nursing, ITHA Transfer Department, viewed 29 March 2009, from http://intertribalhealth.com/ pdfs/pub4.pdf.

Polit, D.F. \& Beck, C.T., 2006, Essentials of nursing research: Methods, appraisal and utilization, Lippincott Williams \& Wilkins, New York.

Pross, E., 2003, 'International nursing students: A phenomenological perspective', Nurse Education Today 23(6), 396-403.

Quinn, F.M. \& Hughes, S.J., 2007, Quinn's principles and practice of nurse education, 5 th edn., Nelson Thornes, London.

Tortumluoglu, G., 2006, 'The implications of transcultural nursing models in the provision of culturally competent care', ICUS and Nursing Web Journal 25.

Uys, L.R. \& Gwele, N.S., 2005, Curriculum development in nursing: Process and innovation, Routedge, London.

Weber, J. \& Kelley, J., 2007, Health assessment in nursing, 3rd edn., Lippincot Williams \& Wilkins, New York.

Wu Y., 2000, 'Interpersonal communication and caring experiences with clients from the perspective of student nurses', unpublished master's thesis, University of Namibia. 